\title{
COMPARATIVE STUDY OF KNOWLEDGE AND SOCIAL ENVIRONMENT FOR ADOLESCENTS WHICH INFORMATION PROGRAMS AND TEENAGER COUNSELING ABOUT EARLY MARRIAGE IN STATE HIGH SCHOOLS IN KONAWE KEPULAUAN DISTRICT
}

\author{
Jumriah Abdullah ${ }^{1}$, Tasnim Tasnim ${ }^{2}$, La Banudi ${ }^{3}$ \\ ${ }^{123}$ Universitas Mandala Waluya, in Kendari Southeast Sulawesi Province, Indonesia
}

Corresponding Author : Jumriah Abdullah

Email : jumabdullah80@gmail.com

\begin{abstract}
Background:Based on data from the Central Statistics Agency of Konawe Islands Regency in 2019, it is known that the number of Senior High Schools is 7 units, with a total of 1,717 students. The results of reports of teenagers who married before the age of 18 in 2019 were as many as 49 people. Based on this, the rate of early marriage in the last 2 years actually shows an increase. Researchers took the theme of early marriage because from the results of preliminary studies conducted by researchers, most adolescents have insufficient knowledge about early marriage and its effects on the social environment of adolescents. So it is not surprising why the rate of early marriage in Konawe Islands Regency is generally the third highest in Southeast Sulawesi Province.

Methods:This research is a quantitative research with a comparative study research type. The population in this study were 332 people and 179 samples with the sampling technique using stratified random sampling.

Results:The statistical results with the Mann Whitney Test shows that the significant value for knowledge was $0.000<$ value $\alpha=0.05$ and the significant value for the social environment of adolescents shows p-value $=0.000<$ value $\alpha=0.05$. That means, that there are differences in knowledge and social environment for adolescents in State Senior High School the Youth Counseling Program and Information which are active and inactive towards early marriage.

Conclusion:There are differences in the knowledge and social environment of adolescents in the senior high School where the Youth Counseling Program and Information which are active and inactive towards early marriage.
\end{abstract}

Key words: Knowledge, Youth, Information, Counseling, Early marriage 


\section{INTRODUCTION}

Youth motivation for early marriage can come from themselves or from others (1). In addition, lack of knowledge about reproductive health causes ignorance of the dangers of early marriage(2). Early marriage not only takes away youth's future but also has negative impacts such as dropping out of school where 85 percent of girls in Indonesia end their education after they get married(3).

Early marriages also pose a high risk of physical, sexual, psychological and emotional violence as well as social isolation where babies born as a result of early marriages also have a higher likelihood of being born prematurely with low birth weight and malnutrition.(4). Early marriage has a negative impact on death where pregnancy is the main cause of death for girls aged 15-19 years.Girls aged 10-14 years have five times the risk of dying during pregnancy or childbirth compared to the 2024 year age group while this risk doubles in the 15-19 year age group (5).

In line with the high number of early marriages, the number of adolescents who gave birth for the first time at the age of 15-19 is quite high in Southeast Sulawesi, namely 41.22 percent. There are five districts in the highest region including Konawe Regency at 54.86\%, Konawe Selatan Regency (54.02\%), Konawe Islands Regency (45.66\%), Muna Regency (26.25\%) and the last order is Kendari City. namely as much as $16.79 \%(6)$.

Researchers took the theme of adolescent knowledge about early age marriage because from the results of preliminary studies conducted by researchers, most adolescents have less knowledge about early age marriage. So it is not surprising why the rate of early marriage in Konawe Islands Regency is generally the third highest in Southeast Sulawesi Province. With this research, researchers hope to eliminate the perception of parents to marry off their children at an early age, and prevent early marriage among adolescents so that it can reduce the number of early marriages in Konawe Islands Regency(7).

Based on the results of the interview, it is known that the factors causing the rate of early marriage in Konawe Islands Regency are mostly due to the lack of knowledge of adolescents about the risks of early marriage and public belief that it is time for adolescents to get married so that they do not become a burden to their parents. This is supported by a UNICEF study which explains that socio-cultural interactions can be the cause of early marriage and this factor is very difficult to control. For economic reasons, the hope of achieving social and financial security after marriage causes many parents to encourage their children to marry at a young age(8).

\section{METHOD}

This research is a quantitative research with a comparative type of study(9). The population in this study were 249 students of class X and class XI of West Wawonii 1 State Senior High School and 83 South Wawonii 1 High School students, so that the total population was 332 people. The sample amounted to 179 people with the sampling technique using stratified random sampling(10).

\section{RESULTS}

Table 1 shows that the category of knowledge for respondents in West Wawoni State Senior High School is 113 people $(84.3 \%)$ and the poor category is 21 people (15.6\%), while the category of knowledge is sufficient in South Wawonii State Senior High School as many as 25 people $(55.6 \%)$ and 20 people $(44.4 \%)$ in less category.

Table 2 shows that the social environment for respondents from West Wawoni Senior High School is in the positive category of 104 people $(77.6 \%)$ and the negative category is 30 people $(22.4 \%)$, while the positive category of the social environment in the South Wawonii State 
Senior High School is 20. people (44.4\%) and in the negative category were 25 people $(55.6 \%)$.

Table 3 shows that based on the test results with the Mann Whitney TestThe significant number shows the value of pvalue $=0.000<\alpha=0.05$, it can be concluded that there is a difference in the knowledge of adolescents in public high schools with active and inactive youth counseling

programs and information about early marriage.

Table 4 shows that based on the test results with the Mann Whitney Test The significant value shows the value of pvalue $=$ $0.000<\alpha=0.05$, it can be concluded that there are differences in the social environment of adolescents in public high schools where the Adolescent Counseling Program and Information is active and inactive towards early marriage.

Table 1

Distribution of Respondents' Knowledge about Early Marriage based on Active Adolescent Counseling Programs and Information in Wawonii Barat Public High School and South Wawonii State High School

\begin{tabular}{c|c|c|c|c|c}
\hline \multirow{2}{*}{ No. } & \multirow{2}{*}{ Knowledge } & \multicolumn{3}{|c}{ Determinants of Early Marriage } \\
\cline { 3 - 6 } & & \multicolumn{2}{|c|}{ West Wawonii } & \multicolumn{2}{c}{ South Wawonii } \\
\cline { 3 - 6 } & & $\mathrm{n}$ & $\%$ & $\mathrm{n}$ & $\%$ \\
\hline 1 & Enough & 113 & 84.3 & 25 & 55.6 \\
\hline 2 & Less & 21 & 15.7 & 20 & 44.4 \\
\hline \multicolumn{2}{|c|}{ total } & 134 & 100 & 45 & 100 \\
\hline
\end{tabular}

Table 2

Distribution of Respondents' Social Environment on Early Marriage based on Active Youth Counseling Programs and Information in Wawonii Barat Public High School and South Wawonii State High School

\begin{tabular}{c|c|c|c|c|c}
\hline \multirow{2}{*}{ No. } & \multirow{2}{*}{ Social environment } & \multicolumn{3}{|c}{ Determinants of Early Marriage } \\
\cline { 3 - 6 } & & \multicolumn{2}{|c|}{ West Wawonii } & \multicolumn{2}{c}{ South Wawonii } \\
\cline { 3 - 6 } & $\mathrm{n}$ & $\%$ & $\mathrm{n}$ & $\%$ \\
\hline 1 & Positive & 104 & 77.6 & 20 & 44.4 \\
\hline 2 & Negative & 30 & 22.4 & 25 & 55.6 \\
\hline \multicolumn{2}{r|}{ total } & 134 & 100 & 45 & 100 \\
\hline
\end{tabular}

Table 3

Analysis of Respondents' Knowledge Difference Based on the Activeness of the Adolescent Counseling Program and Information in Wawonii Barat State Senior High School and Wawonii Selatan Public High School

\begin{tabular}{c|c|c|c|c|c}
\hline \multicolumn{2}{c|}{ West Wawonii } & \multicolumn{2}{|c|}{ South Wawonii } & \multirow{2}{*}{$\begin{array}{c}\text { Mann } \\
\text { Whitney Test }\end{array}$} \\
\hline Enough & Less & Enough & Less & & \\
\hline 113 & 21 & 25 & 20 & 179 & 0,000 \\
\hline
\end{tabular}

Source: Mann Whitney analysisTest 
Table 4

Analysis of Respondents' Social Environment Differences Based on the Activeness of Youth Counseling Programs and Information in Wawonii Barat Public High School and Wawonii Selatan Public High School

\begin{tabular}{c|c|c|c|c|c}
\hline \multicolumn{2}{c|}{ West Wawonii } & \multicolumn{2}{c|}{ South Wawonii } & & $\begin{array}{c}\text { Mann } \\
\text { Whitney Test }\end{array}$ \\
\hline Positive & Negative & Positive & Negative & n & \\
\hline 104 & 30 & 20 & 25 & 179 & 0,000 \\
\hline
\end{tabular}

Source: Mann Whitney Test analysis

\section{DISCUSSION}

\section{Knowledge}

Knowledge is the result of knowing, and this happens after people sense a certain object. Sensing occurs through the five human senses, namely the senses of sight, smell, hearing, touch and taste. Most of human knowledge is obtained from sight and hearing which are very important domains in an action(11).

Measurement of knowledge can be done by interview or questionnaire that asks about the content of the material to be measured from the research subject or respondent into the knowledge that you want to know or measure, and can be adjusted to the levels of knowledge. Knowledge is a very important domain for the formation of one's actions (over behavior) from experience and research has shown that behavior based on knowledge will be more lasting than behavior that is not based on knowledge.

The results showed that the tradition of respondents from West Wawoni Senior High School in the category of believing was as many as 93 people $(70.9 \%)$ and the category of disbelief was 39 people $(29.1 \%)$, while the tradition category of believing in the South Wawonii Senior High School was as many as 32 people $(71.1 \%)$ and in the distrust category were 13 people $(28.9 \%)$. This means that an active youth counseling program and information is proven to increase adolescent knowledge. This can be seen in high schools with active youth counseling programs and information, so the knowledge of adolescents tends to improve and vice versa, in high schools with inactive adolescent counseling programs and information, adolescent knowledge tends to be no less. Other than that,

The results showed that there was a significant difference in knowledge between high school and active adolescent counseling program and information and high school with inactive adolescent counseling information and program. The results of this study are in line with research conducted by(12) who found differences in knowledge between respondents who received information about reproductive health and those who did not.

Respondents with good knowledge are more likely to avoid early marriage. This is because with good knowledge, they will understand better about reproductive health, the dangers of free sex and the importance of getting married when the reproductive organs are ready, so that they will be more organized and prevent early marriage. This is in accordance with the theory presented in(13)that the factors causing health problems are behavioral and non-behavioral factors. Behavioral factors are influenced, one of which is predisposing factors, namely factors that are manifested in knowledge, belief, belief, values and demographic variations. This factor is more of an individual nature.

\section{Social environment}

Experience is one of the factors that influence a person(14). The majority of adolescents tend to discuss their problems 
with peers than adults even though they have more experience in terms of age. Even on problems that are considered very serious, teenagers tend to discuss it with their peers (friends). When the problem is told to adults, it is usually because they do not find a solution when discussed with others. This happens because teenagers often have interest and commitment as well as strong ties due to the assumption that only their group is able to understand the problem.

Test results with the Mann Whitney Test The significant value shows the value of pvalue $=0.000<\alpha=0.05$, it can be concluded that there are differences in the social environment of adolescents in public high schools with active and inactive youth counseling programs and information on early marriage. This research is in line with research conducted by Retno (2019) with the results of statistical tests between peer variables and perceptions, obtained a value of $p=0.035 \quad(p<0.05)$, so it can be concluded that there is a difference in the proportion of respondents who have a good perception of marriage below. age of respondents who have peers who are not supportive compared to respondents who have peers who support underage marriage.

Dannayanti.Y, et al stated that there was a significant difference in premarital sex behavior among adolescents who had peers with active sexual behavior compared to those who had peers with passive premarital sex behavior $(p=0.004)$. Furthermore, information about risky sexual behavior from peers can prevent adolescents from engaging in it. If peers do not provide information, it can increase the risk of adolescents to do so up to 2.6 times.

Peers are a very influential factor in character building in adolescents. The current phenomenon shows a tendency for adolescents to always be with their peers. The high intensity of interaction between adolescents and their peers will form strong emotional bonds while at the same time emotional ties with parents tend to be reduced. The emotional links that are formed will open up opportunities for discussion and exchange of information that are able to form patterns of thought and behavior so that fellow youth group members influence each other in shaping character among them.

The need for strong social support which is believed to be proven to be able to provide mental strength to prevent adolescents from falling into negative associations(15). Social support that is meant is reinforcing support, namely good relations with parents, siblings, adults and peers. So it needs guidance, counseling and community empowerment, then it needs cross-sector participation and involvement as well as parties who can set an example in society(16).

\section{CONCLUSION}

There are differences in the knowledge and social environment of adolescents in State Senior High Schools where the Youth Counseling Program and Information are active and inactive towards early marriage at the State Senior High School of KonaweKepulauan Regency. It is also hoped that students will choose wisely their friends who are used as a place to exchange information, and it is hoped that there will be an even distribution of information for all students so that no one else gives wrong information.

\section{REFERENCES}

1. Setiawati ER, Marnelly TR. The effect of early merriage to harmonious husband and wife in Bagan Bhakti Village,Balai Jaya Sub-district, Rokan Hilir District. Jurnal Online Mahasiswa (JOM) Bidang Ilmu Sosial dan Ilmu Politik. 2017;4(1):1-13 (Indonesia).

2. Pranata L. Overview of female teenagers' knowledge about health reproduction in SMAN 1 class $\mathrm{X}$ 
Lalan Musi Banyuasin. Jurnal Akademika Baiturrahim Jambi. 2018;7(2):92-9 (Indonesia).

3. Harari YN. Homo Deus: Human future : Pustaka Alvabet; 2018 (Indonesia).

4. Puspasari HW, Pawitaningtyas I. Mother and child health problem and child with early merriage in some Ethnics in Indonesia; Impacts and prevention. Buletin Penelitian Sistem Kesehatan. 2020;23(4):275-83 (Indonesia).

5. Fadlyana E, Larasaty S. Early merriage and problems. Sari Pediatri. 2016;11(2):136-41(Indonesia).

6. BKKBN. The prevalence of ASFR, TFR and average of UKP based on districts/ city. In: Nasional BKDKB, editor. Kendari: BKKBN; 2015 (Indonesia).

7. Health Department of Konawe Kepulauan District. The number of early merriage. Konawe Kepulauan District. 2019.

8. Dwinanda AR, Wijayanti AC, Werdani KE. The relationship between mother's education and thier knowledge about early merriage. Jurnal Kesehatan Masyarakat Andalas. 2017;10(1):7681 (Indonesia).

9. Mackey A, Gass SM. Second language research: Methodology and design: Routledge; 2015.

10. Sugiyono. Noanparametric Statistics for research. 2015.

11. Notoatmodjo S. Health Research Methodology. 2014 (Indonesia).

12. Budiono MA, Sulistyowati M. The role of School health program in giving health information about health reproduction for female students in government SMP $\mathrm{X}$ in Surabaya. Jurnal Promkes. 2013;1(2):184-91 (Indonesia).

13. Sari GNSN, Fitriana S, Anggraini DH. Factors of education, knowledge, parity, family supprot and family income which relate to antenatal service use. Jurnal Ilmu dan Teknologi
Kesehatan.

2015;2(2):77-82

14. Tasnim T, Depu AH. Experience and training relate to performance clean and healthy living behaviour in Cadre in the working area of Poasia Primary Health Care, Kendari City: Clean and Healthy Living Behavior. Indonesian Journal Of Health Sciences Research And Development (IJHSRD). 2020;2(3):74-9.

15. Dumilah R, Fariji A, Petralina B. Effect of friends, family environment and culture to teenagers' perception about ealry merriage. Jurnal Ilmiah Bidan. 2019;4(1) (Indonesia).

16. Jayadipraja EA, Prasetya F, Azlimin A, Mando WOSY. Family clean and healthy living behavior and its determinant factors in the village of Labunia, Regency of Muna, Southeast Sulawesi Province of Indonesia. Public Health of Indonesia. 2018;4(1):39-45. 